sures which have been taken in the last few years to strengthen scientific research have unquestionably helped, but so long as the number of students reading physics remains at the present low level, the long-term outlook for Danish physics will remain uncertain. Not only is a steady flow of talented recruits into the field essential for its future vitality, but the number of staff positions in the universities also depends primarily on the number of students to be taught. Since opportunities in the traditional occupation of high-school teaching are declining, it is vital that the employment of physicists in Danish industry, which is at present at a very modest level, be stimulated.

It would be useful if other national physical societies would carry out and publish similar studies, to help provide a sound basis for international comparisons.

\section{TRENDS IN PHYSICS 1984}

The Proceedings of the EPS 6th General Conference held in Prague 27-31 August 1984 are now published in two volumes of over 700 pages. The local Organizing Committee under J. Kaczer and the editors, J. Janta and J. Pantofliček have done an excellent job not least in "extracting" from almost all the authors of plenary and invited papers the necessary manuscripts (only a few of which are in the form of extended abstracts) and illustrations. Altogether in addition to the 13 Plenary Lectures, 103 invited papers (out of 107) are included plus seven papers specially recommended by symposia organisers that had been presented orally.

Copies may be ordered from the Secretariat in Geneva:

Price to IOMs: Sw.Fr. 40.-

Others: $\quad$ Sw.Fr. 70.-

\section{ERICE SCHOLARSHIPS}

Applications for the scholarships that have been put at the disposal of EPS by the Ettore Majorana Centre, for courses at Erice should be made to the EPS Secretariat in Geneva. Note that candidates must be established physicists who are either EPS Individual Members themselves or sponsored by an EPS Individual Member, and that scholarships are available only for those schools that are sponsored by EPS.

\section{NUCLEAR PHYSICS SUMMER SCHOOL}

Europhysics News regrets having misquoted in the March issue the dates of the Nuclear Physics Summer School to be held in Mikolajki, Poland. This will run from 2-14 September 1985, not 26 Aug.-7 Sept. as quoted.

Further information from:

E. Gierlik, Inst. of Experimental Physics, Warsaw University, 69 Hoza St.,

PL-00681 Warsaw

\title{
Research Associateship in Experimental Nuclear Physics
}

There is a vacancy for an experimental physicist to join the nuclear physics group as a Research Associate at the Daresbury Laboratory, an establishment of the Science and Engineering Research Council situated in the north Cheshire countryside.

The group is involved in a research programme on the Nuclear Structure Facility, a large tandem accelerator which currently is operating at up to $20 \mathrm{MV}$ on terminal.

Currently, the principle areas of study are: direct reactions with light and heavy ions, production of exotic nuclei far from stability, nuclei with very high angular momentum, nuclear breakup and fragmentation and studies of isotope shifts and hyperfine structure using laser-induced resonance fluorescence. Experimental equipment includes a Q3D magnetic spectrometer, advanced gamma-ray and neutron detection apparatus, and a lm diameter scattering chamber. An isotope separator with an associated dilution refrigerator and a beam line for laser studies has recently been brought into full operation, a recoil separator is in an advanced commissioning stage, and a heavy-ion polarised source is under construction.

Applicants (male/female) should possess a $\mathrm{PhD}$ degree or expect to obtain one during 1985.

An appointment will be made at a salary between $£ 9,977$ and $£ 11,220$ per annum depending on age, ability and experience. The post is available for a fixed term of three years and is superannuable.

CLOSING DATE: Sunday 30th June, 1985.

For further information please write or telephone: Dr. J. Lilley on Warington (0925) 65000 Ext. 558.

Application forms may be obtained from and should be returned quoting reference $\mathrm{DL} / 912$ to: The Personnel Officer,

Science \& Engineering Research Council

Daresbury Laboratory, Daresbury, Warrington, Cheshire, WA4 4AD.

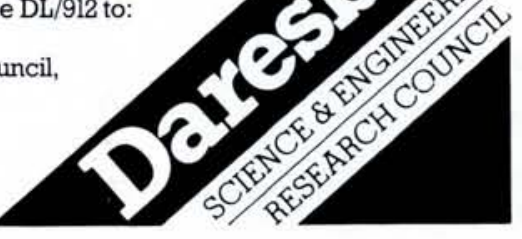

EPS Divisions, Sections and Group

Astronomy and Astrophysics Division Solar Physics Section

Atomic and Molecular Physics Division

Atomic Spectroscopy Section

Chemical Physics

Chemical Physics

Molectronic and Ator

Computational Physics Group

Condensed Matter Division

Liquids Section

Low Temperature Physics Section

Macromolecular Physics

Magnetism

Metal Physics

Semiconductors and Insulators

Surfaces and Interfaces

High Energy \& Particle Physics Division

Nuclear Physics Division

Optics Division

Plasma Physics Division

Quantum Electronics Division
Europhysics News is the official journal of the European Physical Society which comprises 29 National Societies, Academies and Group, over 3500 Individual Members and 66 Associate Members. Governing bodies of EPS are the General Meeting, Council and an elected Executive Committee responsible for detailed policy. EPS promotes the collaboration of physicists throughout Europe, organising and harmonising conferences and publications, improving physics education, encouraging physics applications, awarding scholarships to sponsored schools in Erice. EPS publishes in addition to EN, Europhysics Conference Abstracts, E. Ed. News and, in collaboration with The Institute of Physics (UK), the European Journal of Physics. Individual Members receive EN free of charge (price to institutions: Sw.Fr. 90.-/a), rebates on the price of many publications and on conference fees. Annual EPS membership fee for Individual Members belonging to an EPS member society is: Sw.Fr. 40.-; independent members: Sw.Fr. 120.-; members of a Collaborating Society, e.g. the American Physical Society: Sw.Fr. 50.- (\$25).

\section{Editor: E.N. Shaw}

Meetings Compilation: W.S. Newman

Editorial Board:

K. Appert, A. Baratoff, B. Jacrot,

G.R. Macleod, M. Mayor, J. Muller

Editorial and Advertising Office at the EPS Secretariat

Address: EUROPEAN PHYSICAL SOCIETY P.O. Box 69 . CH-1213 Petit-Lancy 2 Switzerland

Telephone: Geneva (22) 931130

Telex: $\mathbf{4 2 3} \mathbf{4 5 5}$ dema ch

Cables: europhys genève

Printed by: Pfirter frères sa $\mathrm{CH}-1213$ Petit-Lancy/Switzerland 